\title{
KOGNITYWNY ZINTEGROWANY SYSTEM INFORMATYCZNY ZARZĄDZANIA WSPOMAGAJĄCY BIG MANAGEMENT
}

\author{
Andrzej Bytniewski, Marcin Hernes \\ Uniwersytet Ekonomiczny we Wrocławiu
}

\begin{abstract}
Streszczenie: Współczesne organizacje gospodarcze stoją przed wyzwaniem wdrażania koncepcji Big Management, czyli realizacji procesu zarządzania z uwzględnieniem nowych paradygmatów w połączeniu ze zjawiskiem Big Data. W tym celu konieczne jest zastosowanie nowych rozwiązań wspomagających zarządzanie. Celem niniejszego artykułu jest przeanalizowanie możliwości wykorzystania kognitywnego zintegrowanego systemu informatycznego zarządzania wspomagającego Big Management. W artykule przedstawiono charakterystykę koncepcji Big Management, biorąc pod uwagę nowe paradygmaty zarządzania i zjawisko Big Data oraz przeanalizowano funkcjonowanie i właściwości kognitywnego zintegrowanego systemu informatycznego zarządzania z punktu widzenia jego zastosowania w realizacji Big Management.
\end{abstract}

Słowa kluczowe: zintegrowane systemy informatyczne zarządzania, paradygmaty zarządzania, Big Data, Big Management

DOI: 10.17512/znpcz.2016.3.1.01

\section{Wprowadzenie}

Zmienny charakter gospodarki, rozwój technologii informatycznych, globalizacja i nieograniczony przepływ wiedzy powoduje, że organizacje gospodarcze muszą szybko reagować na zmiany zachodzące zarówno w ich wnętrzu, jak i w otoczeniu. Rozwiązywanie problemów wymusza na zarządzających przedsiębiorstwami podejmowanie złożonych decyzji o charakterze operacyjnym, taktycznym, ale przede wszystkim strategicznym, które wiążą się z przyszłością organizacji. Podejmowanie decyzji w przedsiębiorstwie realizowane jest najczęściej w warunkach ryzyka i niepewności, ponieważ nie można przewidzieć skutków podjętej decyzji lub przewidzieć ich z bardzo małym prawdopodobieństwem. Organizacje stają zatem przed koniecznością stosowania nowych paradygmatów zarządzania (scharakteryzowanych w kolejnym punkcie). Dodatkowo występuje zjawisko Big Data, czyli zbyt dużej ilości danych, zbyt mocno nieusystematyzowanych i zbyt szybko podlegających zmianom, aby można było w ich przypadku zastosować tradycyjne metody zarządzania danymi (Robak, Franczyk, Robak 2013, s. 1203-1209). W konsekwencji pojawia się konieczność zmiany w klasycznym podejściu do zarządzania i przyjęcie koncepcji Big Management, zdefiniowanej w pracy Towards Big Management (Bytniewski, Hernes 2016) jako realizacja procesu zarządzania $\mathrm{z}$ uwzględnieniem nowych paradygmatów w połączeniu $\mathrm{z}$ koncepcją Big Data. Jako podstawowe wyzwania stawiane Big Management określono (Bytniewski, Hernes 2016): 
- obniżanie kosztów,

- podnoszenie jakości,

- uzyskanie przewagi konkurencyjnej,

- pozyskiwanie i przetwarzanie informacji w czasie rzeczywistym,

- podejmowanie decyzji w czasie zbliżonym do rzeczywistego,

- automatyczne podejmowanie decyzji (szczególnie zrutynizowanych),

- wzrost jakości prognoz gospodarczych,

- podnoszenie kwalifikacji pracowników.

Należy wyraźnie podkreślić, że realizacja koncepcji Big Management w odniesieniu do stawianych wyzwań wymaga zastosowania nowych narzędzi informatycznych wspomagających zarządzanie.

Celem niniejszego artykułu jest przeanalizowanie możliwości wykorzystania kognitywnego zintegrowanego systemu informatycznego zarządzania w celu wspomagania Big Management.

W pierwszej części artykułu przedstawiono charakterystykę koncepcji Big Management, biorąc pod uwagę nowe paradygmaty zarządzania i zjawisko Big Data. Następnie przeanalizowano funkcjonowanie i właściwości kognitywnego zintegrowanego systemu informatycznego zarządzania z punktu widzenia jego zastosowania w realizacji Big Management.

\section{Charakterystyka Big Management}

Autorzy pracy (Bytniewski, Hernes 2016) podkreślają, że istotą Big Management jest integracja nowych paradygmatów zarządzania z koncepcją Big Data.

Analizując problematykę nowych paradygmatów zarządzania, zauważymy, że w pracach (Drucker 2000; Grudzewski, Hejduk 2011, s. 95-111) zostały one określone następująco:

1) Zarządzanie jest specyficzną i wyróżniającą się cechą każdej organizacji i nie ogranicza się do „zarządzania w biznesie”, aż 90\% problemów, jakimi zajmuje się organizacja, ma charakter ogólny, a tylko $10 \%$ spraw organizacji biznesowej jest różnych od organizacji non-profit (sektor publiczny).

2) W swoich działaniach należy korzystać $z$ różnych struktur organizacyjnych, a koncentrować się na jednej właściwej, gdyż nie występuje jedyny model uniwersalnej organizacji. Dlatego też organ zarządzający powinien nauczyć się szukać, rozwijać i poddawać testom różne formy organizacji i wybrać tę, która jest najbardziej odpowiednia dla osiągnięcia założonego celu.

3) Zadaniem menedżera i organizacji jest przewodniczenie ludziom, a nie kierowanie nimi. Jej głównym celem jest wykorzystanie umiejętności i wiedzy każdego z zatrudnionych dla osiągnięcia wzrostu produktywności pracy. Nie istnieje więc jedyny właściwy sposób kierowania ludźmi.

4) Podstawą zarządzania powinny być wartości i potrzeby klientów, które mają wpływ na decyzje dotyczące dystrybucji ich dochodów. Technologia i produkt danej firmy oraz rynki finalnych użytkowników jej produktów (rynek, na którym działa) nie może być produktem wyjścia dla zarządzania. 
5) Zarządzanie nie jest określone prawnie i musi mieć charakter funkcjonalny i obejmować cały proces. Zarządzanie musi koncentrować się na wynikach i działaniach w ciągu tworzenia całego procesu ekonomicznego. Przewaga powiązań ekonomicznych nad kontrolą prawną przynosi większy efekt.

6) Zakres zarządzania nie powinien być określony politycznymi granicami państwa, które są ważnym czynnikiem organizacyjnym. Polityka zarządzania sfery biznesu musi być definiowana pod względem funkcjonalnym, a nie politycznym.

7) Domeną zarządzania nie jest wnętrze organizacji. Zarządzanie jest narzędziem osiągnięcia zamierzonych wyników w otoczeniu zewnętrznym, w którym działa.

8) Sustainability - zdolność przedsiębiorstwa do ciągłego uczenia się, adaptacji i rozwoju, rekonstrukcji, reorientacji.

Realizowanie procesu zarządzania $\mathrm{z}$ wykorzystaniem nowych paradygmatów wiąże się z potrzebą podejmowania decyzji w czasie zbliżonym do rzeczywistego, bazując na najbardziej aktualnych i wartościowych informacjach. Jest to warunkiem koniecznym do zarządzania przedsiębiorstwem w sposób efektywny i skuteczny. Jednocześnie należy zauważyć, że środowisko funkcjonowania przedsiębiorstwa w gospodarce opartej na wiedzy charakteryzują następujące zjawiska, będące wyznacznikiem Big Data (Davenport, Paul, Bean 2012):

- wysoki wolumen danych wynikający ze złożoności procesów, personalizacji oferty i tendencji dopasowania oferty nawet do najmniejszych grup klientów;

- nieznane pochodzenie, struktura i zawartość danych, które będą wykorzystywane w celu przeprowadzania analiz;

- duża zmienność danych w czasie, która implikuje zjawisko dynamiki i złożoności modeli ekonomicznych, w jakich funkcjonują przedsiębiorstwa.

Zatem system informatyczny realizujący koncepcję Big Management powinien, między innymi, posiadać następujące własności (SAS b.r.):

- efektywność i elastyczność w zakresie funkcjonalnym oraz przetwarzania dużych wolumenów danych,

- realizowanie procesów przetwarzania i zarządzania wiedzą w sposób zintegrowany,

- generowanie propozycji decyzji lub automatyczne podejmowanie decyzji,

- realizowanie procesu ciągłego uczenia się,

- umożliwienie dostosowania realizacji procesów biznesowych do potrzeb klientów,

- posiadanie funkcji analitycznych będących narzędziami w pracy analityków biznesowych,

- odpowiadanie na zadawane pytania oraz realizowanie analiz w czasie zbliżonym do rzeczywistego, usprawniając tym samym pracę analityków i projektantów,

- umożliwianie tworzenia interaktywnych analiz danych, których wyniki dostarczane są także na urządzenia mobilne.

Jednym z systemów posiadających przedstawione właściwości jest kognitywny zintegrowany system informatyczny zarządzania, scharakteryzowany $\mathrm{w}$ dalszej części artykułu. 


\section{Kognitywny zintegrowany system informatyczny zarządzania}

Realizacja systemu wspierającego Big Management możliwa jest wyłącznie poprzez wykorzystanie w jego budowie wielu rodzajów technologii informacyjno-komunikacyjnych. Do najważniejszych z nich możemy zaliczyć:

1. Chmurę obliczeniową (Cloud Computing), którą można zdefiniować jako usługi (serwisy) obliczeniowe oferowane przez podmioty zewnętrzne i dostępne na życzenie w dowolnym momencie, skalujące się dynamicznie w odpowiedzi na zmieniające się zapotrzebowanie użytkowników (Mateos, Rosenberg 2011). Funkcjonowanie systemów informatycznych wspomagających zarządzanie w ramach usług chmury obliczeniowej umożliwi efektywne wykorzystanie zasobów, co w konsekwencji pozwoli na obniżenie kosztów związanych z infrastrukturą informatyczną, ponoszonych przez przedsiębiorstwo. Użytkownik systemu będzie bowiem płacił za wdrożenie systemu i tylko za wykorzystane zasoby infrastruktury (sprzęt, oprogramowanie systemowe i użytkowe) użytkowane w trakcie jego eksploatacji.

2. Przetwarzanie rozproszone (Grid Computing), nazywane również równoległym, realizowanym przez sieć komputerów, w którym zadania obliczeniowe są dzielone, a następnie każdy fragment jest wykonywany równolegle przez pulę maszyn zdefiniowaną w środowisku gridowym.

3. Przetwarzanie danych realizowane przez silnik bazy danych (in-Database) - zadania obliczeniowe są wykonywane równolegle wewnątrz bazy danych, tak aby wykorzystać mechanizmy i architekturę masowego przetwarzania równoległego (Massive Parallel Processing) oferowanego przez coraz większą grupę producentów systemów zarządzania bazą danych (na przykład Teradata, IBM, SAS, Oracle).

4. Przetwarzanie danych w pamięci operacyjnej (In-Memory Databases) - system zarządzania bazą danych przystosowany do przetwarzania danych i zdarzeń w pamięci operacyjnej (RAM), z całkowitym pominięciem nośników dyskowych. Baza danych przystosowana jest do wykorzystania bezpośrednio w warstwie aplikacyjnej. Zastosowanie nowoczesnych rozwiązań strukturalnych oraz daleko idące uproszczenie architektury systemu zarządzania bazą danych umożliwia osiąganie efektywności i przepustowości niedostępnych dla tradycyjnych baz danych.

5. Technologie inteligentne, a zwłaszcza kognitywne programy agentowe - realizują funkcje poznawcze i decyzyjne, takie, jakie zachodzą w ludzkim mózgu, dzięki temu ,posiadają" umiejętność rozumienia rzeczywistego znaczenia obserwowanych zjawisk i procesów biznesowych. Umożliwiają one nie tylko szybki dostęp do informacji oraz szybkie wyszukanie tej nas interesującej, jej analizę i wyciąganie wniosków, ale również, oprócz reagowania na bodźce z otoczenia, posiadają zdolności poznawcze umożliwiające uczenie się poprzez doświadczenie empiryczne zdobywane na drodze bezpośredniej interakcji z otoczeniem, co w konsekwencji pozwala na automatyczne podejmowanie i realizowanie decyzji (Bytniewski i in. 2015). 
Przedstawione technologie wykorzystywane są w budowie prototypu kognitywnego zintegrowanego systemu informatycznego zarządzania (Cognitive Integrated Management Information System - CIMIS). Przyjęto, że składa się on z następujących podsystemów (Rysunek 1):

- środków trwałych,

- logistyki,

- zarządzania produkcją,

- zarządzania zasobami ludzkimi,

- finansowo-księgowego,

- controllingu,

- CRM (Customer Relationship Management),

- Business Intelligence.

Podsystem środków trwałych obejmuje wspomaganie realizacji procesów związanych z finansową obsługą środków trwałych i naliczaniem ich amortyzacji. Podsystem umożliwia automatyczne generowanie dowodów księgowych (na przykład polecenie księgowania amortyzacji) wykorzystywanych przez podsystem finansowo-księgowy, dokonywanie wyceny środków trwałych na określony dzień, jak również przeprowadzenie inwentaryzacji $\mathrm{z}$ generowaniem raportów w różnych układach.

Podsystem logistyki wspomaga realizację zadań z zakresu planowania zaopatrzenia materiałowego i dystrybucji wyrobów gotowych, gospodarki materiałowej i magazynowej, gospodarki wyrobami gotowymi, modelowania sieci dystrybucyjnej, zarządzania transportem, jak również optymalizacji przewozów (na przykład poprzez rozwiązywanie problemu komiwojażera).

Podsystem zarządzania produkcją wspomaga procesy przedsiębiorstwa realizowane głównie w działach: technologicznym, konstrukcyjnym oraz planowania (Kapeliński 2011). Umożliwia realizację funkcji z zakresu technicznego przygotowania produkcji planowania zdolności produkcyjnych, planowania produkcji, planowania zużycia materiałowego, planowania i realizacji zleceń, sterowania produkcją, monitorowania produkcji, wizualizacji i archiwizacji dokumentacji procesu produkcji, jak również przekazania wyrobów gotowych do magazynu.

Podsystem zarządzania zasobami ludzkimi wspomaga realizację takich funkcji, jak ewidencjonowanie danych pracowników firmy, ich umów z zakładem pracy, ewidencjonowanie czasu pracy, naliczanie wynagrodzeń, tworzenie formularzy na potrzeby deklaracji podatkowych i ubezpieczeniowych, rozliczanie podróży służbowych, opracowywanie statystyk zatrudnienia, wynagrodzeń i czasu pracy (Bytniewski (red.) 2015).

Podsystem finansowo-księgowy, wspomaga ewidencjonowanie, w pełnym zakresie, zdarzeń gospodarczych (ujmowanych w postaci zagregowanej z podsystemów stycznych), dostarcza również istotnych, z punktu widzenia zarządzania przedsiębiorstwem, informacji, dotyczących między innymi zdolności płatniczych, przychodów, kosztów, wyniku finansowego, marży, rentowności.

Podsystem controllingu automatycznie przetwarza dane związane $\mathrm{z}$ rachunkiem kosztów i wyników, współpracując $\mathrm{z}$ podsystemem finansowo-księgowym. W podsystemie realizowane są funkcje dotyczące zarówno controllingu strategicz- 
nego (którego zadaniem jest opracowywanie planów strategicznych i ustalanie odchyleń od jego realizacji oraz w zakresie podstawowych kierunków rozwoju przedsiębiorstwa), jak i operatywnego (którego zadaniem jest rejestracja zużycia czynników produkcyjnych oraz wartości i ilości wytworzonej produkcji, porównując je z wielkościami planowymi).

Podsystem CRM wspomaga realizację całokształtu zagadnień związanych z zapewnieniem jak najlepszych więzi z klientami, gromadzeniem informacji o ich preferencjach i potrzebach w celu zwiększenia efektywności sprzedaży. Informacje dostarczane przez CRM pozwalają na optymalizację strategii rynkowych, sprzedaży, serwisu oraz właściwe prowadzenie kampanii reklamowych (Bytniewski (red.) 2015).

Podsystem Business Intelligence, służy do wspomagania decyzji biznesowych, dzięki inteligentnemu wykorzystaniu dostępnych już w firmie zasobów danych (Hernes, Matouk 2013, s. 1253-1258). Zadaniem podsystemu Business Intelligence jest umożliwienie łatwego i bezpiecznego dostępu do znajdujących się w firmie danych, obsługi procesów ich analizy oraz dystrybucji raportów (szczególnie przekrojowych) w obrębie przedsiębiorstwa i jego partnerów biznesowych.

W budowie CIMIS wykorzystane zostały kognitywne programy agentowe. $\mathrm{Na}$ Rysunku 1 zaprezentowano strukturę logiczną systemu CIMIS.

W systemie zakłada się, że w początkowej fazie wszystkie agenty są w stanie „nienauczonym”. Mogą one zostać wstępnie pogrupowane zgodnie potrzebami przedsiębiorstwa $\mathrm{w}$ zakresie podsystemów, na przykład pewna grupa agentów należy do podsystemu logistyki, inna do podsystemu zarządzania produkcją, a jeszcze inna do podsystemu finansowo-księgowego.

W ramach tych grup agenty mogą zostać wstępnie „nauczone” przez firmę wdrażającą system. Dalszy etap uczenia agentów pogrupowanych oraz niepogrupowanych (czyli niezależnych, realizujących głównie zadania związane analizą funkcjonowania wszystkich podsystemów i podejmowaniem decyzji) realizowany jest przez pracowników przedsiębiorstwa. Przykładowo każdy pracownik może uczyć jednego lub kilku agentów, aby docelowo wykonywali różnego rodzaju prace za człowieka (na przykład przyjmowanie zamówień, obsługa zaopatrzenia materiałowego, planowanie produkcji, realizacja zleceń produkcyjnych, magazynu, wystawianie faktur). Zakłada się również, że nauczone agenty będą podejmowały decyzje zamiast człowieka, zwłaszcza na szczeblu operacyjnym oraz taktycznym. Programy agentowe mogą uczyć się również samodzielnie poprzez analizę skutków swoich decyzji.

Celem głównym funkcjonowania agenta nadzorującego (Supervisor) jest kontrola poprawności funkcjonowania pozostałych agentów, głównie w zakresie integracji wiedzy. Agent ten analizuje, w czasie zbliżonym do rzeczywistego, struktury wiedzy wszystkich agentów. W sytuacji wystąpienia niespójności wiedzy automatycznie wykonywany jest algorytm bazujący na metodzie wykorzystującej teorię consensusu, a wynik działania agenta przyjmowany jest w systemie jako aktualny stan wiedzy. 
Należy również zwrócić uwagę że wszystkie podsystemy ZSIZ połączone są jednym, spójnym strumieniem informacji i wiedzy dostępnym online, w czasie rzeczywistym dla kierownictwa.

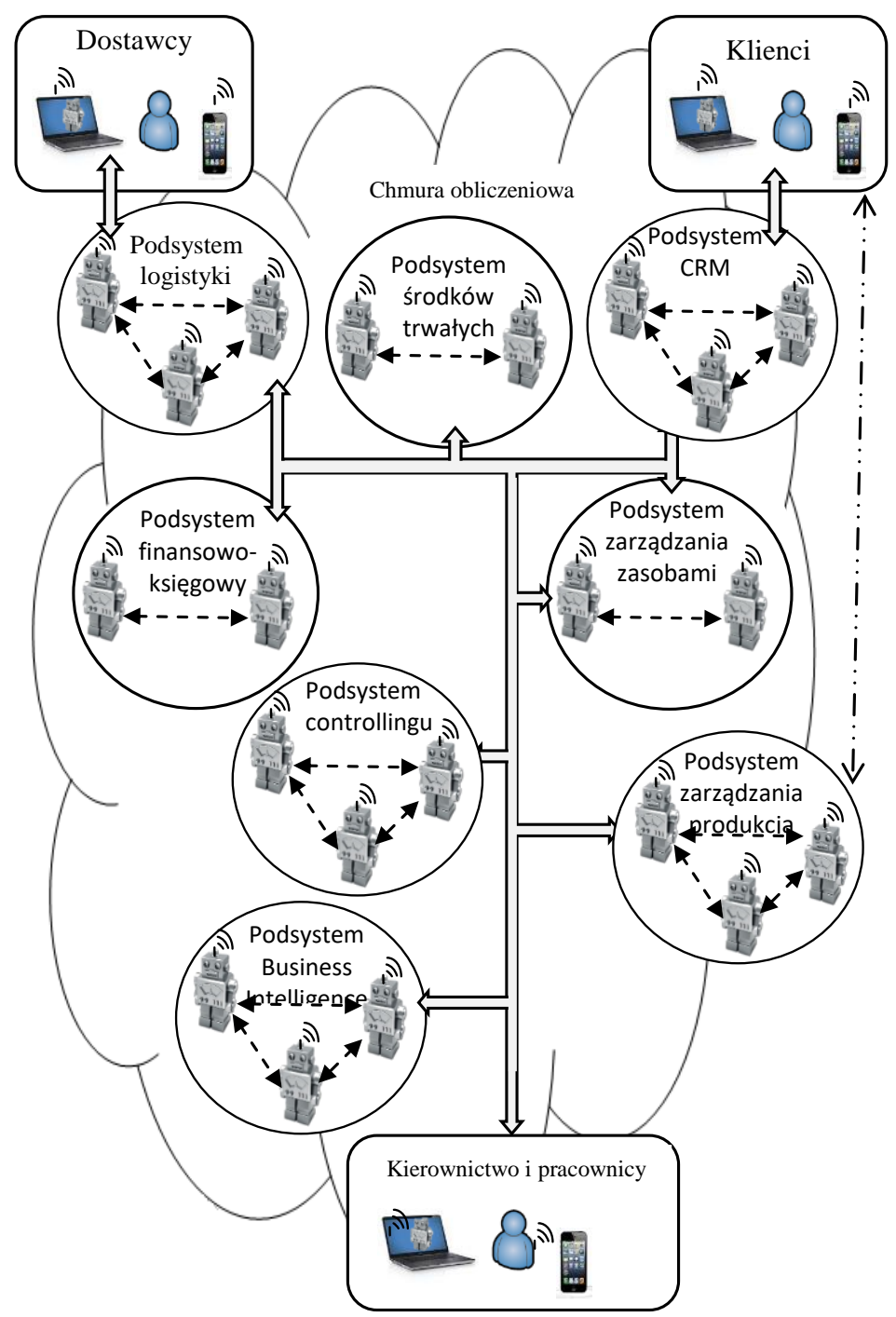

Legenda:
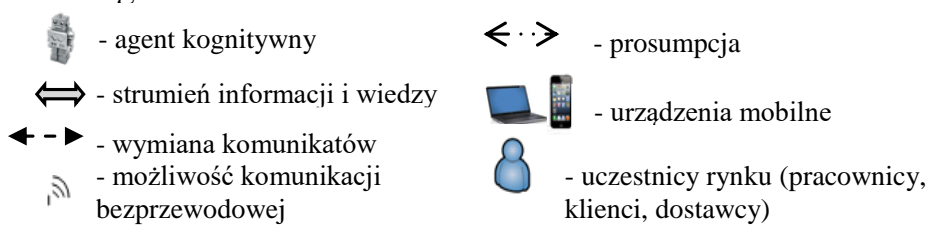

\section{Rysunek 1. Architektura systemu CIMIS}

Źródło: Opracowanie własne 
Podsumowując, w odniesieniu do wymagań Big Management system CIMIS charakteryzuje się:

- wspomaganiem realizacji procesów biznesowych we wszystkich obszarach działalności przedsiębiorstwa, $\mathrm{z}$ wykorzystaniem najnowszych technologii informacyjno-komunikacyjnych;

- zintegrowaniem procesu przetwarzania i zarządzania wiedzą (zarówno ustrukturalizowaną, jak i nieustrukturalizowaną) poprzez pełny przepływ informacji i wiedzy pomiędzy podsystemami oraz integrację tej wiedzy; procesy te mają również wpływ na podnoszenie kwalifikacji pracowników;

- możliwością automatycznego podejmowania decyzji oraz realizacją procesu ciągłego uczenia się (ze względu na zastosowanie kognitywnych programów agentowych);

- możliwością dokonywania różnego rodzaju analiz oraz tworzeniem raportów dla kierownictwa.

Można zatem wyciągnąć wniosek, że system CIMIS w znacznym stopniu wspomaga realizację koncepcji Big Management przez organizacje gospodarcze, szczególnie te, które mają rozbudowane struktury organizacyjne i są terytorialnie rozmieszczone oraz działanie ich wymaga wykorzystania Big Data z otoczenia.

\section{Podsumowanie}

Reasumując rozważania prezentowane w niniejszym artykule, można wyciągnąć wniosek, że koncepcja Big Management zakłada ścisłą koherencję obszarów zarządzania i informatyki, w efekcie tworząc fundament koncepcyjny kognitywnego zintegrowanego systemu informatycznego zarządzania. $\mathrm{Z}$ tego też względu współczesne organizacje gospodarcze stają przed wyzwaniem wdrażania nowoczesnych systemów informatycznych, do których właśnie można zaliczyć system CIMIS. Umożliwia on wspomaganie realizacji procesu zarządzania, bazując na nowych paradygmatach przy jednoczesnym uwzględnieniu zjawiska Big Data. Dzięki wykorzystaniu systemu CIMIS możliwe jest bowiem podejmowanie decyzji w czasie zbliżonym do rzeczywistego na podstawie najbardziej aktualnych i wartościowych informacji.

Dalsze prace badawcze powinny dotyczyć, między innymi, doskonalenia procesów uczenia się agentów kognitywnych oraz rozszerzenia systemu o funkcje wspierające korzystanie z ,internetu rzeczy” w działalności gospodarczej.

\section{Literatura}

1. Bytniewski A. (red.) (2015), Architektura zintegrowanego systemu zarzadzania, Wydawnictwo Uniwersytetu Ekonomicznego we Wrocławiu, Wrocław.

2. Bytniewski A., Chojnacka-Komorowska A., Hernes M., Matouk K. (2015), The Implementation of the Perceptual Memory of Cognitive Agents in Integrated Management Information System, [w:] Barbucha D., Nguyen N.T., Batubara J. (eds.), New Trends in Intelligent Information and Database Systems, Studies in Computational Intelligence, Vol. 598, Springer International Publishing Switzerland. 
3. Bytniewski A., Hernes M. (2016), Towards Big Management, Federated Conference on Computer Science and Information Systems, Gdańsk 2016 (artykuł zgłoszony na konferencję).

4. Davenport T.H., Paul B., Bean R. (2012), How 'Big Data' Is Different, "MIT Sloan Management Review", Vol. 54, No. 1.

5. Drucker P.F. (2000), Management Challenges for 21st Century, Harper Business, New York.

6. Grudzewski W.M., Hejduk I.K. (2011), Przedsiębiorstwo przyszłości. Zmiany paradygmatów zarządzania, „Master of Business Administration”, Vol. 19, No. 1, s. 95-111.

7. Hernes M., Matouk K. (2013), Knowledge Conflicts in Business Intelligence Systems, [w:] Proceedings of Federated Conference Computer Science and Information Systems, s. 1253-1258, FedCSIS, Kraków.

8. Kapeliński W. (2011), Systemy zaawansowanego planowania i harmonogramowania produkcji jako uzupetnienie funkcjonalności systemów ERP, [w:] Bytniewski A. (red.), Informatyka ekonomiczna. Informatyka w biznesie, Wydawnictwo Uniwersytetu Ekonomicznego we Wrocławiu, Wrocław.

9. Mateos A., Rosenberg J. (2011), Chmura obliczeniowa. Rozwiązania dla biznesu, Helion, Gliwice.

10. Robak S., Franczyk B., Robak M. (2013), Applying Big Data and Linked Data Concepts in Supply Chains Management, Annals of Computer Science and Information Systems, Proceedings of Federated Conference Computer Science and Information Systems (FedCSIS), s. 1203-1209, FedCSIS, Kraków.

11. SAS (b.r.), Big Data. What it is and why It Matters, http://www.sas.com/en_us/insights/bigdata/what-is-big-data.html (dostęp: 15.03.2016).

\title{
A COGNITIVE INTEGRATED MANAGEMENT INFORMATION SYSTEM FOR SUPPORTING A BIG MANAGEMENT
}

\begin{abstract}
A modern economic organizations face the challenge of implementing the concept of Big Management - management with regard to new paradigms in conjunction with the phenomenon of Big Data. For this purpose it is necessary to apply the new business management software. The aim of this paper is to examine the possibility of the use of cognitive integrated management system for supporting a Big Management. The paper presents the characteristics of the concept of Big Management, taking into account the new paradigms of management and the phenomenon of Big Data. Also the functioning and properties of an cognitive integrated management information system, from the point of view of its use in the implementation of Big Management, has been analyzed.
\end{abstract}

Keywords: integrated management information systems, paradigms of management, Big Data, Big Management 